\title{
State of rheumatic fever in Algeria. Viewpoint of a cardiac surgeon.
}

\author{
Abdelmalek Bouzid*, Salim Chibane, Mohamed Atbi, Halima Larbi, Boukri Hamouda, Redha Djilali-Sayeh, \\ Youcef Larabi, Tarek Hamdi, Sami Bouchenafa, Ramdan A Ould Abderrahmane \\ From World Society of Cardiothoracic Surgeons 25th Anniversary Congress, Edinburgh \\ Edinburgh, UK. 19-22 September 2015
}

\section{Background/Introduction}

In Algeria prevalence of rheumatic fever(RF) has steadily decrease especially after the establishment of the national program against the RF in 1990; the national incidence decreased from $04.7 / 100,000$ in 2002 to $02.5 / 100,000$ in 2003, $02.3 / 100,000$ in 2004, in 2009 the national incidence decreased to $1.01 \mathrm{cas} / 100,000$ of 04 to 19 years.

However, the share of rheumatic patients requiring surgical treatment for valvular lesions has not changed, indicating the insufficiency of the modified Jones criteria.

\section{Aims/Objectives}

Our aim is to evaluate the sensitivity of the Jones criteria for the diagnosis of rheumatic fever in patients with rheumatic valve disease.

\section{Method}

77 patients were operated for pure rheumatic mitral stenosis, from January 2009 to May 2012 at the cardiac surgery department of the EHU 1 November 54.

The sex ratio was 0.33 ; the average age was 42.26 years $95 \%$ [39.84-44.68].

Rheumatic lesion was confirmed by pure stenotic lesion of the mitral valve.

\section{Results}

Only one patient of the 77 patients (1.3\%) had a history of rheumatic fever diagnosed and treated; the remaining 76 patients $(98.7 \%)$ who have never been diagnosed or treated for rheumatic fever, until the appearance of valvular lesions which indicated surgery.

Department of Cardiac Surgery, EHU 1er Novembre 54, Oran 31000, Algeria

\section{Discussion/Conclusion}

Despite the favorable results of the national program against the RF; However cardiac surgery departments are still receiving patients with valvular rheumatic lesions, which have never been diagnosed or treated, this testifies to the insufficiency of Jones criteria for the diagnosis of rheumatic fever, other criteria must be introduced for the diagnosis (echocardiography, biological); the aim being to reduce the socio-economic impact of this disease, and why not eradicate definitively rheumatic fever.

Published: 16 December 2015

doi:10.1186/1749-8090-10-S1-A3

Cite this article as: Bouzid et al: State of rheumatic fever in Algeria.

Viewpoint of a cardiac surgeon.. Journal of Cardiothoracic Surgery 201510 (Suppl 1):A3.

Submit your next manuscript to BioMed Central and take full advantage of:

- Convenient online submission

- Thorough peer review

- No space constraints or color figure charges

- Immediate publication on acceptance

- Inclusion in PubMed, CAS, Scopus and Google Scholar

- Research which is freely available for redistribution

Submit your manuscript at www.biomedcentral.com/submit 